\title{
Learning Cycle for Literacy Financial of Early Childhood Education
}

\author{
Nira Gardynia ${ }^{1}$, Ernawulan Syaodih ${ }^{2}$ \\ \{Niragardynia8@gmail.com ${ }^{1}$,ernawulansy@upi.edu ${ }^{2}$ \} \\ Universitas Pendidikan Indonesia, Bandung, Indonesia ${ }^{1,2}$
}

\begin{abstract}
Financial literacy can be cultivated as early as possible for children, especially through early childhood education. Financial literacy is still rarely applied to early childhood. Some are reluctant to involve children about finances because they are too young. This happens because the time is not for children to get stimulated literacy. Meanwhile, literacy will be needed by children in their daily life. Fostering financial literacy in early childhood education requires an appropriate learning model, one of which is by using a learning cycle learning model consisting of exploration, planning, production, communication, and reflection. Based on this, the purpose of this article is to analyze, reveal, and provide information about what financial literacy early childhood should have and how the learning cycle can foster financial literacy in early childhood. This article is expected to add new knowledge for educators in implementing financial literacy in early childhood education.
\end{abstract}

Keywords: Learning cycle, Literacy financial, Early childhood

\section{Introduction}

Every child is born in a pure state (fitrah). Children are individuals who experience a process of rapid development and are fundamental to the next life. The growth and development of the natural potential of every child to achieve harmony and perfection in all its aspects can be through education, which is a process of transformation and internalization of knowledge, values, and abilities in children [1]-[3]. One of them is through the early childhood education, where according to Mursid (2015) Early childhood education is an effort to provide stimulation, guidance, care, and provision of learning activities that will produce children's abilities and skills [4].

Education cannot be separated from learning, because both of them are an inseparable unit [5]. To provide stimulation to early childhood education, proper learning is needed. The learning process can be teacher-centered and student-centered. One of student-centered learning is learning cycle learning. This learning cycle is a learning cycle, where each phase makes children play an active role in mastering competencies in the learning objectives to be achieved. [6],[7]. Learning cycles according to Pebruanto (2007) consist of exploring, planning, producing, communicating, and reflecting [8]. The National Curriculum and Entrepreneurship (Ciputra Way K12) which adopts a learning cycle learning model, in which children are equipped to create entrepreneurial projects based on their talents and interests, with a creative learning approach to improve children's life skills and self-confidence and children are trained to have a basis for entrepreneurial thinking to produce something new. 
Through early childhood education, various kinds of literacy are provided. According to Kementerian Pendidikan dan Kebudayan (2017), there are six basic literacies, namely, language literacy, numeracy literacy, scientific literacy, digital literacy, financial literacy, and cultural literacy and citizenship [9].

When parents often find children aged 5-6 years who are being invited by their parents to go to the mall, the child asks for toys and when the parents do not buy them the child tends to cry and even throw tantrums. This is the same when it was found in an early childhood education institution when children came home from school asking to buy toys, even though there were already many toys at home. In general, this illustrates how children can not distinguish between their needs and wants. This is an indicator of financial literacy. This will have an impact on financial decision making as an adult and have an adverse effect on personal finances and ultimately become global. Financial literacy is a core life skill for participating in modern society. Children grow up in an increasingly complex world where they ultimately need to take over their own financial future.

The existence of an appropriate learning process, the expected goals will be achieved, so the researchers are interested in knowing what financial literacy early childhood should have and how the learning cycle fosters early childhood financial literacy.

\section{Literature Review}

Literacy is the ability to read and then develop into reading and writing skills [10]. However, literacy is a series of abilities to manage various information from various aspects of life [11],[12]. According to the Ministry of Education and Culture (2017), there are six basic literacies, namely literacy, numeracy, scientific literacy, financial literacy, digital literacy, and cultural literacy and citizenship [9]. In general, literacy is no longer reading and writing but has a broader meaning consisting of a good understanding of various aspects of life. There are six basic literacies, one of which is financial literacy.

Financial literacy is a fairly new thing in the world of education, even though financial literacy has actually existed since August 23, 1787, at which time John Adams stated the need for financial literacy to Thomas Jefferson by letter [13]. Financial literacy according to Hunget al. is a specific form of knowledge, the ability or skills to apply that knowledge, perceived knowledge, good financial behavior, and even financial experience [14]. Meanwhile, according to the Ministry, according to Tanuwidjaja (2008) literacy is a basic skill to form a mindset so as to form a character to make a decision [15]. Education and Culture (2017) financial literacy is the knowledge and skills to apply the knowledge that has been gained and the skills acquired in order to make effective decisions in a financial context to improve financial well-being, both individually and socially, and to participate in the community [9]. Thus financial literacy is knowledge about finance wisely in acting and being responsible in taking financial risks.

The scope of financial literacy according to the Kementerian Pendidikan dan Kebudayaan (2017) is as follows [9]: 
Table 1. The scope of financial literacy

\begin{tabular}{|c|c|}
\hline Content & Explanation \\
\hline $\begin{array}{l}\text { Definition of economic transactions and various } \\
\text { types of practice }\end{array}$ & $\begin{array}{l}\text { Definition of medium of exchange, goods and } \\
\text { services }\end{array}$ \\
\hline Introduction of economic resources (earnings) & $\begin{array}{l}\text { Human Resources (HR). Human resources for } \\
\text { livelihood / profession to fulfill basic needs. }\end{array}$ \\
\hline $\begin{array}{l}\text { Introduction of the concept of spending as meeting } \\
\text { basic needs }\end{array}$ & $\begin{array}{l}\text { Priority scale, namely primary, secondary and } \\
\text { tertiary needs }\end{array}$ \\
\hline $\begin{array}{l}\text { Understand the concept of saving in traditional and } \\
\text { modern terminology }\end{array}$ & Save \\
\hline $\begin{array}{l}\text { Introduction to the concept of sharing based on local } \\
\text { wisdom and religious teachings }\end{array}$ & Charity \\
\hline $\begin{array}{l}\text { Introducing the concept of bad practice and financial } \\
\text { crime }\end{array}$ & Corruption \\
\hline
\end{tabular}

Finance in early childhood can be introduced in the form of concepts about money, saving, financial institutions, and needs and desires. Meanwhile in Ariyani's [16] research at TK Khalifah Purwokerto by integrating monotheism and financial literacy, it covers five scopes, namely the introduction of transactions (introducing nominal money in market-market roleplaying activities), the introduction of economic resources (introducing professions and working with parents to choosing homework), introduction to the concept of shopping (in activities not clearly defined but the teacher teaches the needs and desires as well as the introduction of the daily lifestyle), introduction to the concept of saving (habituation of saving activities), and introduction of prohibited practices in finance (activities telling stories about attitudes honest). Basic theory of financial literacy in early childhood, namely cognitive learning theory by Piaget, Jerome Bruner, and Albert Bandura, and factors that affect early childhood finances, one of which is the child's own economic experience. As for financial literacy in several countries, according to APEC (2014) financial literacy in Australia, where the knowledge that has been obtained by children is so that children are confident and make responsible decisions, in China financial literacy in early childhood is introduced about the concept, use, savings, and money creation, while in Mexico financial literacy in early childhood is introduced through interactive digital games the main goal is to achive basic financial literacy, as well as to develop positive habits and attitudes towards financial institutions.

Learning cycle is a learning model based on constructivism, where children build their knowledge through their involvement in the learning process so that the learning process is student centered [17],[18],[4]. According to Ali (1993) learning cycle is a learning process in which there are stages or series of activities carried out appropriately and regularly [19]. According to Pebruanto (2007), the learning cycle is divided into five stages, namely exploring, planning, producing, communicating, and reflecting. Thus, financial literacy in early childhood can be in the form of knowledge and behavior [8]. 


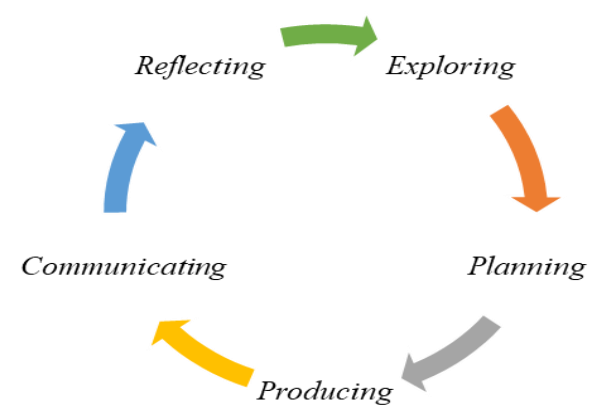

Fig 1. Learning Cycles [8]

\subsection{Exploring}

Children are allowed to build their knowledge based on their experiences through their curiosity with questions and facilitated observations [8],[20].

\subsection{Planning}

This stage is where children pour ideas and ideas that are under the information they have obtained into planning and involve the children to analyze the exploring that has been carried out [21]. This planning stage is important to attract children's interest and stimulate further activities [22].

\subsection{Producing}

This stage is where the children's ideas, concepts, skills are expressed in the form of a concrete work that can be observed by others [23].

\subsection{Communicating}

This stage, where the child communicates the results of his work to other people. Children try to communicate what they have done and children can build social interactions with the surrounding environment (friends, teachers, and parents).

\subsection{Reflecting}

This stage is an evaluation stage, where the child identifies what has been achieved as well as the obstacles and obstacles he has encountered as an improvement in the next project [23].

Based on Putri's research (2018), the learning cycle with the stages of exploration, planning, doing, communicating, and reflecting becomes a facility to develop creative character, caring, curiosity, enthusiasm, and responsibility [24]. Meanwhile, according to Newton (2006) the learning cycle will reflect the experiences that have been obtained constructively [25]. Meanwhile, according to Sherraden, Johnson, Guo, and Elliott children will develop the understanding that has been obtained through successive stages of development [26]. 


\section{Method}

The approach used in this study uses a qualitative approach that is library research. Library research aims to collect, process, and conclude data from theoretical studies, references, and scientific studies to find out what financial literacy early childhood should have and how the learning cycle can foster financial literacy in early childhood [27],[28]. The steps for library research activities can be carried out as follows: 1) Selection of topics, at this stage the topics selected are based on the researcher's interest in financial literacy for early childhood education literacy and the possibility of research success, 2) Information exploration, at this stage the source of information is taken from research data collected by analyzing theories based on journals, books, theses, and other research results regarding the learning cycle for early childhood financial literacy, 3) Determining the focus of research, the focus of research that will be examined in this research is the learning cycle for financial literacy for early childhood education, 4) Collecting data sources, at this stage, the data sources are collected by documenting, namely collecting data or documents that have previously been analyzed. 5) Preparation of data presentation, at this stage content analysis, is carried out from each data source that has been collected, and 6) Preparation of reports, Compiling reports with predetermined systematics [29].

\section{Discussion}

Financial literacy that can be possessed by early childhood, including children being able to know the means of exchange for goods and services, children can get to know various types of professions, know between needs and desires, save, share with their teachers and other people, and train children's honesty not to take action corruption.

Learning activities in early childhood using thematic, where children will actively seek, explore, and find concepts [30]. The learning cycle is a learning cycle in which one theme is raised, for example the main theme is the environment and the sub-theme of public places, where in the exploring stage, children are introduced directly to public places such as traditional markets or supermarkets directly, at this stage the curiosity they have by children will bring up ideas in children in accordance with the goals and targets that have been set, children will know about the price of goods, profession, and needs and desires. Furthermore, in the planning stage, where from several sources that have been obtained by the child so that the child gets an idea at the exploring stage, at this stage the idea is put into a complete plan, for example the child will plan to sell the product with how it is packaged, how much, and how much the price it will sell. Next is the production stage, at this stage the ideas that have been poured into planning are then poured into a work, after what the children have planned, they can be poured into market day activities, the work or goods that the children make can be bought and sold in this activity. The fourth stage is the communication stage, the child communicates the results of his work to others both to teachers, parents, and friends to be appreciated.When in market day activities the child's work will be appreciated by means of the buying and selling process and when buying and selling activities the child will be trained honesty to deliver goods at a predetermined price, or to give back to the buyer. Production and communication stages can be carried out simultaneously. Next is the fifth stage, namely the reflection stage, where after all the stages have been passed, the child will reflect on what has been achieved, how he feels, and what are his shortcomings. Taap reflection will make a fixing material for the future. 


\section{Conclusion}

Learning cycle with five stages, namely exploring, planning, producing, communicating and reflecting. Where when exploring the teacher can choose a theme to bring up ideas or ideas in children, at this stage the introduction of economic resources, introduction to the concept of shopping and sharing will be obtained when children explore a place, for example a market or supermarket. Furthermore, in the planning stage where the child's ideas and ideas will be poured into the planning, the child will recognize the means of exchange when determining what goods to sell and at what price. The producing stage of children's planning will be poured into a work, where children will recognize economic transactions such as works that children have made will be exchanged for money and at the communicating stage the work will be communicated so that they will get an award where at this stage the child will recognize the concept of bad practice and financial crimes such as children will give goods with an amount of money received with the help of the teacher in stating the nominal money and return the money when the money is more. The last stage is reflection, where children will reflect on what they have achieved in the stages that have been passed or have not yet been achieved

\section{References}

[1] Kurniawan, D. 2009. Bukhari muslim. Bandung: PT.Mizan Pustaka.

[2] Nata, A. 1997. Filsafat Pendidikan Islam. Jakarta: Logos Wacana Ilmu.

[3] Abdul, M \& Muhaimin. 1993. Pemikiran Pendidikan Islam. Bandung: Trigenda karya.

[4] Mursid. 2015. Pengembangan pembelajaran PAUD. Bandung: PT Remaja Rosdakarya.

[5] Fadlillah. 2014. Edutaiment Pendidikan anak usia dini menciptakan pembelajaran menarik, kreatif, dan menyenangkan. Jakarta: Kencana.

[6] Ngalimun. 2014. Strategi dan model pembelajaran. strategi dan model pembelajaran. Yogyakarta: Aswaja presindo.

[7] Fajaroh, F \& Dasna, I, W. 2007. Pembelajaran dengan model siklus belajar (learning cycle). Jurusan Kimia FMIPA UM. [Online]. http://lubisgrafura.wordpress.com/2007/09/20/pembelajarandengan.

[8] Pebruanto, D. S. W. 2007. Creating strong foundations for the future entrepreneurs. Surabaya: Ciputra Foundation.

[9] Kementerian Pendidikan dan Kebudayaan. 2017. Literasi finansial. Jakarta: Tim GLN Kemendikbud.

[10] Goody, J. 1999. The implications of literacy. In D, A. Wagner, R.L. Venetsky, \& B.V. Street (Eds.), Literacy: An international handbook. Boulder, CO: Westview Press. pp. 29-33.

[11] Alberta. 2009. Special education branch. Canada: Alberta Education.

[12] Ekowati, D. W., \& Suwandayani, B. I. 2019. Literasi numerasi untuk sekolah dasar. Malang: Universitas Muhamaiyah Malang.

[13] Hidajat, T. 2015. Literasi keuangan. Semarang: STIE Bank PBD Jateng.

[14] Hung, A., Parker, A. M, \& Yoon, J. 2009. Defining and measuring financial literacy. RAND Labor and Population.

[15] Tanuwidjaja, W. 2008. 8 intisari kecerdasan finansial. Jakarta: PT. Buku Kita.

[16] Ariyani, D. 2018. Pendidikan literasi keuangan pada anak usia dini TK khalifah purwokerto. Jurnal: Yin Yang, 13: pp.175-190.

[17] Akbar, E. 2020. Metode belajar anak usia dini. Jakarta: Kencana.

[18] Marwiyah, Alauddin \& Ummah, K. 2018. Perencanaan pembelajaran kontemporer berbasis penerapan kurikulum 2013. Yogyakarta: Deepublish.

[19] Ali, M. 1993. Guru dalam proses belajar mengajar. Bandung: Sinar Baru Algesindo. 
[20] Muscat, M., \& Mollicone, P. 2012. Using Kolb's Learning Cycle to Enhance the Teaching and Learning of Mechanics of Materials. International Journal of Mechanical Engineering Education. 40(1): pp.66-78.

[21] Arthur, J. C. 2001. Creativity in education and learning: A guide for teachers and education. London: Kogan Page.

[22] Abdullah, J., Halim, S. Y. J., Adlan, A. B. \& Wan, M.W. A. R. 2015. Student and Women Entrepreneurs' Collaboration in Social Entreprise Program at UiTM, Malaysia, Jurnal Procedia Social and Behavioral Sciences. 168: pp.97-103.

[23] Ciputra entrepreneur school. 2009. Aplikasi Pendidikan entrepreneur k-12 ciputra way. Surabaya: Universitas Ciputra Entrepeuneur Center.

[24] Putri, F. R. 2018. Analisis program entrepeuneur dalam mengembangkan karakter anak usia dini: Studi kasus terhadap anak usia 5-6 tahun di TK Santa Ursula Bandung. Tesis. universitas Pendidikan Indonesia (Tidak diterbitkan).

[25] Newton, T. 2006. Script, psychological life plans, and the lerning cycle.Transactional Analysis Journal. 2006; 36(3): Pp. 186-195.

[26] Masnan, A. H \& Curugan, A. A. M. 2016. Financial Education Program for Early Childhood Education. International Journal of Academic Research in Bussiness and Social Sciences. 6(12): pp. 113-120.

[27] Sugiyono. 2012. Memahami penelitian kualitatif. Bandung: Alfabeta.

[28] Khatibah, K. 2011. Penelitian kepustkaan iqra. Jurnal Perpustakaan dan Informasi. 5(01): pp.3639.

[29] Kuhltau, C.C. 2002. Teaching the library research. USA: Scarecrow Press Inc.

[30] Trianto. 2011. Desain pengembangan pembelajaran tematik bagi anak usia dini TK/RA \& anak kelas awal SD/MI. Jakarta: Kencana. 